\title{
Treatment of Breast and Colon Cancer Cell Lines with Anti-Helmintic Benzimidazoles Mebendazole or Albendazole Results in Selective Apoptotic Cell Death
}

\section{Jakeb SSM Petersen}

University of Otago - Dunedin Campus: University of Otago

Sarah Baird ( $\nabla$ s.baird@otago.ac.nz )

University of Otago - Dunedin Campus: University of Otago https://orcid.org/0000-0001-6741-5866

\section{Research Article}

Keywords: tubulin, cell cycle, anti-helmintic, repurposing, apoptosis

Posted Date: April 30th, 2021

DOI: https://doi.org/10.21203/rs.3.rs-450663/v1

License: (c) (1) This work is licensed under a Creative Commons Attribution 4.0 International License. Read Full License 


\section{Abstract}

Purpose: Anti-helmintic drugs mebendazole and albendazole are commonly used to treat a variety of parasitic infestations. They have recently shown some promising results in pre-clinical in vitro and in vivo anti-cancer studies. We compare their efficacy in breast and colon cancer cell lines as well as in noncancerous cells and elucidate their mechanism of action.

Methods: The drugs were screened for cytotoxicity in MDA-MB-231, MCF-7 (breast cancer), HT-29 (colorectal cancer) and mesenchymal stem cells, using the MTT assay. Their effects on the cell cycle, tubulin levels and cell death mechanisms were analysed using flow cytometry and fluorescent microscopy.

Results: Mebendazole and albendazole were found to selectively kill cancer cells, being most potent in the colorectal cancer cell line HT-29, with both drugs having IC50 values of less than $1 \mu \mathrm{M}$ at 48 hours. Both mebendazole and albendazole induced classical apoptosis characterised by caspase- 3 activation, phosphatidylserine exposure, DNA fragmentation, mitochondrial membrane permeability and reactive oxygen species production. Cell cycle arrest in the G2/M phase was found, and tubulin polymerisation was disrupted.

Conclusion: Mebendazole and albendazole cause selective cancer cell death via a mechanism of classical apoptosis and cell cycle arrest, which involves the destabilisation of microtubules.

\section{Introduction}

Mebendazole (MBZ) and albendazole (ABZ) are broad-spectrum benzimidazole anti-helmintic drugs. They are commonly prescribed to treat a range of parasitic worm infections in humans and domestic animals. These drugs have few adverse effects and low cost [1]. The anti-helmintics bind to the colchicine-binding domain of tubulin and inhibit microtubule polymerisation, leading to reduced glucose uptake in the gastrointestinal cells of helminths [2].

MBZ and ABZ have recently been shown to have promising anti-cancer effects in a range of in vitro studies [3-11], as well as in a small number of xenograft models [9,12]. MBZ has also been shown to act in synergy with ionising radiation in melanoma and small cell lung cancer [13] and with non-steroidal anti-inflammatory sulindac in colorectal cancer [12].

Here, we compare this information with the cytotoxicity of MBZ and ABZ in breast and colorectal cancer cell lines and in non-cancerous mesenchymal stromal cells, and describe the mechanism of action by measuring cell cycle progression, microtubule changes and markers of apoptosis, necrosis and oxidative stress.

\section{Materials And Methods}




\section{Materials}

Dimethyl sulfoxide (DMSO) was purchased from Scharlau (Barcelona, Spain). Fetal bovine serum (FBS), penicillin-streptomycin, PBS and trypsin were from Gibco (Carlsbad, CA). 3-(4,5-dimethylthiazol-2-yl)-2,5diphenyl tetrazolium bromide (MTT), mebendazole and albendazole were purchased from Sigma-Aldrich (St. Louis, MO). Paclitaxel was purchased from Cayman Chemical (Michigan, USA). Anti-a-tubulin (DM1A) mouse antibody and anti-acetyl-a-tubulin (Lys40) (D20G3) rabbit antibody were from Cell Signaling Technology (MA, USA).

\section{Cell Culture}

The three human cancer cell lines were MCF-7 (breast adenocarcinoma), MDA-MB-231 (triple negative breast cancer, kind gifts from Prof. Rhonda Rosengren) and HT-29 (colorectal adenocarcinoma, ATCC). The non-cancerous, human bone marrow-derived mesenchymal stromal cell (MSC) line RCB2157 (Riken Biosciences) was also used. All cell lines were cultured in Dulbecco's Modified Eagle Medium (DMEM) with $5 \%$ heat inactivated FBS for cancer cell lines and 10\% for MSCs, 100 units $/ \mathrm{mL}$ penicillin and 100 $\mu \mathrm{g} / \mathrm{mL}$ streptomycin. Cells were incubated at $37^{\circ} \mathrm{C}$ in humidified conditions with $5 \% \mathrm{CO}_{2}$.

\section{MTT Assay}

Cells were seeded and allowed to adhere overnight. They were then treated with MBZ, ALB or DMSO as a vehicle control at $0.1 \% \mathrm{v} / \mathrm{v}$. The quantity of live cells remaining following 24 and $48 \mathrm{hr}$ treatment exposure was measured using the MTT assay, which assesses mitochondrial and endoplasmic reticulum dehydrogenase activity [14]. MTT was added to cells at a final concentration of $0.5 \mathrm{mg} / \mathrm{mL}$, and incubated at $37^{\circ} \mathrm{C}$ for $3 \mathrm{hrs}$. Formazan crystals were dissolved with DMSO, and the resulting absorbance read at $560 \mathrm{~nm}$ using the spectrophotometer.

\section{Flow Cytometry}

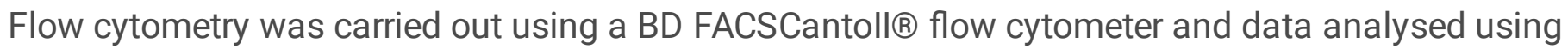
FlowJoß VX software. Cells were treated and after either 24 or 48 hrs were prepared and stained as outlined below, then analysed using the appropriate filters of FITC and/or PE.

\section{Phosphatidylserine exposure}

Following incubation with treatments for 24 or $48 \mathrm{hrs}$, cells and media were harvested, centrifuged at $4^{\circ} \mathrm{C}$, $2000 \mathrm{rpm}$ for 3 mins, the pellet washed twice in $4^{\circ} \mathrm{C}$ PBS and the cells resuspended in Annexin $\mathrm{V}$ binding buffer (HEPES; $10.0 \mathrm{mM}$ (pH 7.4), NaCl; $140.0 \mathrm{mM}$, and $\mathrm{CaCl} 2 ; 2.5 \mathrm{mM}$ ) with propidium iodide (PI) and Annexin $\mathrm{V}$ conjugated to FITC. Cells were incubated for $15 \mathrm{~min}$ in the dark at room temperature.

\section{Mitochondrial membrane permeability}


Cells were treated and harvested, the pellet washed twice in $4^{\circ} \mathrm{C}$ PBS and the cells resuspended in PBS. Tetramethylrhodamine ethyl ester (TMRE) was added to a final concentration of $40 \mathrm{nM}$, then incubated at $37^{\circ} \mathrm{C}$ for 10 mins.

\section{Cell Cycle}

Following incubation with treatments for 24 or $48 \mathrm{hrs}$, media and cells were harvested, centrifuged at $4^{\circ} \mathrm{C}$, $2000 \mathrm{rpm}$ for $3 \mathrm{mins}$, washed twice in $4^{\circ} \mathrm{C}$ PBS and fixed with $70 \%$ ethanol at $4^{\circ} \mathrm{C}$ for $30 \mathrm{mins}$. Cell were washed twice in phosphate-citrate buffer $\left(\mathrm{Na}_{2} \mathrm{HPO}_{4} ; 192 \mathrm{mM}\right.$, citric acid; $4 \mathrm{mM}(\mathrm{pH}$ 7.8)), treated with 100 $\mu \mathrm{g} / \mathrm{mL}$ RNAse A and stained with $50 \mu \mathrm{g} / \mathrm{mL} \mathrm{PI}$.

\section{Caspase activation}

Following treatment of cells for 24 or 48 hours, media and cells were harvested, washed in cold PBS and frozen at $-80^{\circ} \mathrm{C}$ overnight. Cells were then resuspended in buffer (100mM HEPES, $10 \%$ sucrose, $0.1 \%$ CHAPS, $10-4 \%$ Tergitol NP-40 at pH 7.25), DTT added to $5 \mathrm{mM}$ and Ac-DEVD-AMC caspase substrate added to $50 \mu \mathrm{M}$. The plate was incubated in the dark for 2 hours and the AMC fluorescence read at excitation 360nm and emission 460nm.

\section{Oxidative stress}

Oxidative stress levels were analysed by measuring reduced thiol content using the DTNB $(5,5$ "-dithio-bis(2-nitrobenzoic acid)) assay. DTNB quantifies free sulfhydryl groups by producing a measurable yellow product [15]. Using the molar extinction coefficient of $14,150 \mathrm{M}^{-1} \mathrm{~cm}^{-1}$ the free sulfhydryl content can be calculated. Cells were treated, incubated at $37^{\circ} \mathrm{C}$ for $48 \mathrm{hrs}$, harvested and centrifuged at $4^{\circ} \mathrm{C}, 2000 \mathrm{rpm}$ for 3 mins, washed with PBS twice and sonicated for 2 mins. Ten \% SDS and DTNB at final concentration $30 \mu \mathrm{M}$ were added and incubated at room temperature for 30 mins. Absorbance was measured at 412 $\mathrm{nm}$.

\section{Fluorescent Microscopy}

For staining with anti-tubulin antibodies, cells were treated with for 8 hours. Following fixation, cells were blocked for 60 mins in blocking buffer (1X PBS, 5\% BSA, 0.3\% Triton X-100) and stained with primary antibody, anti-a-tubulin at 1:16,000 or anti-acetyl-a-tubulin at 1:800, overnight at $4^{\circ} \mathrm{C}$. After washing, cells were incubated with secondary antibodies and Hoechst 33342 at $10 \mu \mathrm{g} / \mathrm{mL}$ for 1 hour at room temperature in the dark. Prolong Gold was placed on the slides along with coverslips. The cells were analysed using the Nikon Al-R inverted fluorescent microscope with Nikon Intensilight C-HGFI mercury lamp (Olympus, Japan) at 20x magnification.

\section{Statistical Analyses}


Results were analysed using GraphPad Prism ${ }^{\circledR} 6.0$ software. Cell viability, flow cytometry and DTNB experiments $(N=3)$ were analysed using one-way analysis of variance (ANOVA) and Dunnett's post hoc tests with statistical significance at $P<0.05$.

\section{Results}

\section{MBZ and ABZ lower cancer cell viability, especially in colorectal cancer cell line HT29}

The $\mathrm{IC}_{50}$ values of $\mathrm{MBZ}$ and $\mathrm{ABZ}$ over 48 hours were determined in three cancer cell lines MCF-7, MDAMB-231 (both breast cancer) and HT-29 (colon cancer), as well as in the non-transformed mesenchymal stromal-cell line RCB2157, using MTT cell viability assays (Fig 1a-d). The IC $_{50}$ values in the mesenchymal stromal cell line RCB2157 were the highest by several fold (Table 1). The two breast cancer lines were less sensitive to the two drugs than the colorectal cancer cell line HT29.

\section{MBZ and ABZ block the cell cycle at G2/M}

Further analyses were carried out in the HT29 cells to determine the mechanism of the loss of cell viability after 24 or 48 hours treatment with MBZ or ABZ. Progression through the cell cycle was analysed using fixation and staining with propidium iodide (PI). Paclitaxel, known to cause a block in the cell cycle at G2/M through binding to microtubules, was used as a positive control.

Treatment with $2 \mu \mathrm{M}$ MBZ or ABZ or $50 \mathrm{nM}$ paclitaxel resulted in significantly large increases in the $\mathrm{G} 2 / \mathrm{M}$ phase compared to control (Fig. 1e-f). At 24 hours, MBZ was at 60.18\%, ABZ at 58.68\% and paclitaxel at $62.42 \%$ compared to vehicle-only control at $21.37 \%(P>0.05)$. There were smaller, but still significant increases of cells in the $>\mathrm{G} 2 / \mathrm{M}$ phase, and concomitant decreases in the proportion of cells in the $\mathrm{G} 1$ and S phases.

\section{MBZ and ABZ induce apoptotic nuclear morphology and depolymerise microtubules}

In order to investigate whether MBZ and ABZ interact with microtubules in a similar way to paclitaxel, HT29 cells were stained for nucleus and microtubules following treatment with MBZ $(2 \mu M), A B Z(2 \mu M)$, paclitaxel $(50 \mathrm{nM})$ or DMSO vehicle control $(0.1 \% \mathrm{v} / \mathrm{v})$ for $8 \mathrm{hrs}$. Hoechst 33342 staining was used for the nucleus, and antibodies against either -tubulin, a main component of the tubulin dimer that polymerises to form microtubules or against acetyl-a-tubulin, an indicator of stabilised microtubules, were used to visualise microtubule structure [16].

MBZ, ABZ and paclitaxel treatments all produced the condensed nuclei characteristic of apoptosis. atubulin and acetylated-a-tubulin both displayed a decreased fluorescent intensity following MBZ and ABZ treatment compared to control. By contrast, paclitaxel increased intensity of both a- and acetylated-a tubulin staining compared to control. This suggests that MBZ and ABZ promote depolymerisation of microtubules, whereas paclitaxe I promotes polymerisation and stabilises microtubules, as expected.

\section{MBZ and ABZ induce caspase-3 activity}


Since it appeared that cell death was occurring concurrently with a block in the cell cycle, characteristics associated with various forms of apoptosis were investigated. Caspase-3 activity was measured in HT-29 cells following treatment with MBZ, ABZ, paclitaxel or vehicle-only control as before (Fig. 2a). Both untreated control and DMSO vehicle control showed low levels of activity. ABZ and MBZ treatment both increased caspase activation around 550-fold at 24 hours $(P<0.0001$ compared to untreated control), which dropped back to $300-400$ fold at 48 hours, suggesting that the cell death process had peaked within the first 24 hours. Paclitaxel treatment caused the greatest increase caspase activity, up to 750fold of control at 24 hours ( $P<0.0001$ compared to MBZ, ABZ and controls), which is not surprising as paclitaxel is a classical apoptosis inducer and activates caspase-3 [17].

\section{MBZ and ABZ cause early phosphatidylserine exposure}

Following both 24 and $48 \mathrm{hr}$ treatments, cells were double-stained with fluorescently labelled Annexin- $\mathrm{V}$ to identify early externalisation of phosphatidylserine residues, and PI to separate out the internal phosphatidylserine exposed to Annexin-V by cell membrane permeability, occurring as a result of primary or secondary necrosis (Fig. 2b,c). Following 24hr treatment, MBZ and ABZ caused approximate 25\% decreases in the percentage of viable cells (negative for both Annexin $\mathrm{V}$ and $\mathrm{PI})$ compared to control $(P<$ 0.0001), similar to that of the positive control paclitaxel (Fig. 2b). MBZ and ABZ caused a significant increase in the percentage of cells with phosphatidylserine exposure, with $22.83 \%$ of MBZ treated cells and $24.17 \%$ of $A B Z$ treated cells positive for Annexin $V$ only, similar to paclitaxel at $20.72 \%$, whereas only $3.37 \%$ of control cells were positive $(P<0.0001)$. Numbers of double stained cells undergoing secondary necrosis after treatment with paclitaxel, MBZ and ABZ all significantly increased to MBZ $5.78 \%, A B Z$ $5.99 \%$ and paclitaxel $7.94 \%$ vs control $2.12 \%(P<0.0001)$. Necrotic cells, positive for PI only, were increased only in MBZ and ABZ treatments compared to control, $3.58 \%$ and $3.48 \%$ vs $0.54 \%$ respectively. Forty-eight-hour treatments produced similar results to that of $24 \mathrm{hr}$ treatments.

\section{MBZ and ABZ treatment results in DNA fragmentation}

Another indicator of apoptosis is the fragmentation of DNA content, known as sub-G1 DNA, measured using fixation of cells and PI staining. Here, following both 24 and $48 \mathrm{hr}$ treatments with MBZ, ABZ and paclitaxel, the percentage of cells with sub-G1 DNA content was significantly increased compared to control (Fig. 2d). After 24hrs, MBZ treatment resulted in $13.84 \%(P=0.001)$ of cells with sub-G1 DNA content, ABZ 11.53\% ( $P=0.026)$, paclitaxel 19.33\% $(P<0.0001)$ and control $6.45 \%$. DMSO caused no statistically significant change. Following $48 \mathrm{hr}$ treatment, all amounts increased, except in the controls.

\section{MBZ and ABZ increase mitochondrial membrane permeability}

HT-29 cells were treated with MBZ, ABZ, paclitaxel, DMSO or left untreated for 24 and 48 hrs and the percentage of cells with higher mitochondrial membrane permeability, indicative of apoptosis, determined using the mitochondrial-targeted stain TMRE. 
In the $24 \mathrm{hr}$ treatments, there were no significant differences between DMSO vehicle control (3.49 $\pm 0.38 \%)$ and control (3.36 $\pm 0.29 \%, P>0.05)$. However, in MBZ, ABZ and paclitaxel treatments there were approximate 6 -fold increases in the percentage of cells with permeabilised mitochondrial membranes (Fig. 2e). Cells exposed to the treatments for $48 \mathrm{hrs}$ exhibited similar results, suggesting that the majority of cells had passed through the earlier phases of apoptosis by this time.

\section{MBZ and $A B Z$ induce oxidative stress, resulting reduced thiol oxidation}

Indirect measurement of reactive oxygen species damage was undertaken using the DTNB assay, which quantifies reduced thiol content, from both protein and glutathione sources. This decreases as a consequence of oxidative stress. Following $48 \mathrm{hr}$ treatments, the reduced thiol concentration was significantly decreased in cells treated with $\mathrm{MBZ}$, to $2.671 \times 10^{-5} \mathrm{M}(P=0.0094), \mathrm{ABZ}$ to $2.646 \times 10^{-5} \mathrm{M}(P$ $=0.0086)$ and paclitaxel to $2.539 \times 10^{-5} \mathrm{M}(P=0.0058)$ in comparison to the control at $4.630 \times 10^{-5} \mathrm{M}$ (Fig. 2f).

\section{Discussion}

The colon cancer cells, HT29, were the most sensitive to MBZ and ABZ with $I_{50}$ s of $1.3 \pm 0.1 \mu \mathrm{M}$ and 1.4 $\pm 0.1 \mu \mathrm{M}$ for $\mathrm{MBZ}$ and $\mathrm{ABZ}$ respectively at 24 hours, and $0.11 \pm 0.07 \mu \mathrm{M}$ and $0.69 \pm 0.42 \mu \mathrm{M}$ at 48 hours. At 48 hours, the HT29 cells were 10- (MCF-7) or 136-fold (MDA-MB-231) more sensitive to MBZ and 12(MCF-7) or 77-fold (MDA-MB-231) more sensitive to ABZ than the breast cancer types tested. While direct comparisons between cancer types have not been made before, similar levels of potency to HT29s have been found in gastric cancer cells for MBZ [6] and ABZ [11] and in squamous cell carcinoma cell lines [8], whereas cell lines representing other cancer types were much less sensitive $[7,9,10]$.

MBZ and ABZ also show selectivity for cancer cells. Much higher concentrations were required to reduce the number of mesenchymal stromal cells. This is supported by previous results showing similar effects in fibroblasts (WI-38), endothelial cells (HUVEC) [3] keratinocytes [8], human foreskin fibroblasts [6] and primary canine fibroblasts [7].

In terms of the mechanism of action, we have shown that in HT29 cells, MBZ and ABZ both decrease proliferation and increase cell death levels. The drugs induce classical apoptosis, characterised by caspase-3 activation, mitochondrial membrane permeability and potential loss, phosphatidylserine exposure, DNA fragmentation and some oxidative stress. Nuclear morphology is also typical of apoptosis, including condensation and blebbing.

The activation of caspases by MBZ and ABZ has been shown before, in a range of cancer cell types, including squamous cell carcinoma [8], gastric cancer [6,11], melanoma [18], leukemia cells [19] and the HT29 cell line [20]. The generation of reactive oxygen species has been demonstrated once before, by $A B Z$ in leukemia cells [19]. 
Other features of apoptosis have also been demonstrated previously, in separate studies.

Phosphatidylserine exposure has been found with MBZ in melanoma [18] and ABZ in gastric cancer cells [11]. Mitochondrial involvement in cell death has been shown by cytochrome $c$ release in lung cancer cells treated with MBZ $[3,4]$. ABZ alters the mitochondrial membrane potential of MCF-7 cells, but only at $100 \mu \mathrm{M}[5]$.

In combination with apoptosis, we have shown that these anti-helmintics also induce a block in the cell cycle at G2/M in HT29 cells, as well as a related depolarisation of microtubules, which is likely to lead to mitotic arrest. The G2/M block is similar to what is found with paclitaxel and has also been shown using $A B Z$ in gastric cancer lines $[6,11]$ and MBZ in lung cancer cell lines $[3,4]$.

Similar changes in microtubules to what was observed in HT29 cells treated with MBZ or ABZ have been found in other cancer cell types and described in a variety of ways. Depolymerisation of tubulin was found as a result of ABZ treatment in leukemia cells [19], ovarian cancer [10], canine glioma [7] and gastric cancer [11] and with MBZ in lung cancer cells [4]. In these last two studies, spindle formation was also shown to be inhibited. In melanoma cells, MBZ treatment caused diffuse staining with anti-alphatubulin antibody, showing microtubule disarray [18]. MBZ and ABZ treatment have also been shown to increase the ratio of soluble to insoluble tubulin in cancer cells, indicating tubulin depolymerisation. This was demonstrated for MBZ in lung cancer cells [4] and ABZ in gastric cancer cells [11].

The findings presented here systematically characterise the classical apoptotic cell death caused by antihelmintic drugs MBZ and ABZ in cancer cells. The apoptotic death is connected to a G2/M cell cycle arrest and the depolymerisation of microtubules. These findings strengthen and bring together the already available but fractured evidence in a wide range of other cancer cells types. We further show that MBZ and ABZ are selective, being many-fold more potent in cancer cells compared to non-cancerous cell types, and also demonstrate that anti-helmintics do not show equal efficacy against every cancer cell type, but do appear to be effective against the colorectal cancer cell line HT29.

\section{Declarations}

Funding: This research was supported by the Department of Pharmacology and Toxicology, School of Biomedical Sciences, University of Otago.

Conflicts of interest/Competing interests: The authors have no conflicts of interest to declare.

Availability of data and material: All data are available from the corresponding author upon reasonable request.

Authors' contributions: SKB designed the study and experiments and prepared the manuscript, JSSMP carried out the experiments and the data analysis and contributed to the manuscript.

Code availability: Not applicable. 
Ethics approvals: Not applicable.

Consent to participate: Not applicable.

Consent for publication: Not applicable.

Clinical trials information: Not applicable.

Acknowledgements: We acknowledge funding from the Department of Pharmacology and Toxicology, School of Biomedical Sciences, University of Otago.

\section{References}

1. Nygren P, Larsson R (2013) Drug repositioning from bench to bedside: tumor remission by the antihelmintic drug mebendazole in refractory metastatic colon cancer. Acta Oncol 53:427-428

2. Russell GJ, Lacey E (1995) Inhibition of $[3 \mathrm{H}]$ mebendazole binding to tubulin by structurally diverse microtubule inhibitors which interact at the colchicine binding site. Biochem Mol Biol Int 35:11531159

3. Mukhopadhyay T, Sasaki J, Ramesh R, Roth JA (2002) Mebendazole elicits a potent antitumor effect on human cancer cell lines both in vitro and in vivo. Clin Cancer Res 8:2963-2969

4. Sasaki J, Ramesh R, Chada S, Gomyo Y, Roth JA, Mukhopadhyay T (2002) The antihelmintic drug mebendazole induces mitotic arrest and apoptosis by depolymeriseing tubulin in non-small cell lung cancer cells. Mol Cancer Ther 1(13):1201-1209

5. Castro LSEPW, Kviecinski MR, Ourique F, Parisotto EB, Grinevivius VMAS, Correia JFG, Filho DW, Pedrosa RC (2016) Albendazole as a promising molecule for tumor control. Redox Biol 10:90-99

6. Pinto LC, Mesquita FP, Soares BM, da Silva EL, Puty B, de Oliveira EHC, Burbano RR, Montenegro RC (2019) Mebendazole induces apoptosis via C-MYC inactivation in malignant ascites cell line (AGP01). Tox In Vitro 60:305-312

7. Lai SR, Castello SA, Robinson AC, Koehler JW (2017) In vitro anti-tubulin effects of mebendazole and fenbendazole on canine glioma cells. Vet Comp Oncol 15(4):1445-1454

8. Zhang QL, Lian DD, Zhu MJ, Li XM, Lee JK, Yoon TJ, Lee JH, Jiang RH, Kim CD (2019) Antitumor effect of albendazole on cutaneous squamous cell carcinoma (SCC) cells. BioMed Res Int, Volume 2019, Article ID 3689517, 9 pages

9. Liu H, Sun H, Zhang B, Liu S, Deng S, Weng Z, Zuo B, Yang J, He Y (2020) ${ }^{18}$ F-FDG PET imaging for monitoring the early anti-tumor effect of albendazole on triple negative breast cancer. Breast Cancer 27:372-380, 2020

10. Chu SWL, Badar S, Morris DL, Pourgholami MH (2009) Potent inhibition of tubulin polymerisation and proliferation of paclitaxel-resistant 1A9PTX22 human ovarian cancer cells by albendazole. Anticancer Res 29:3791-3796, 2009 
11. Zhang X, Zhao J, Gao Z, Pei D, Gao C (2017) Anthelmintic drug albendazole arrests human gastric cancer cells at the mitotic phase and induces apoptosis. Exp Ther Med 13:595-603

12. Williamson T, Bai RY, Staedtke V, Huso D, Riggins GJ (2016) Mebendazole and a non-steroidal antiinflammatory combine to reduce tumor initiation in a colon cancer preclinical model. Oncotarget 7(42):68571-68584

13. Patel K, Doudican NZ, Schiff PB, Orlow SJ (2011) Albendazole sensitizes cancer cells to ionizing radiation. Rad Oncol 6:160

14. Mosmann T (1983) Rapid colorimetric assay for cellular growth and survival: application to proliferation and cytotoxicity assays. J Immunol Methods 65(1-2):55-63

15. Ellman GL (1959) Tissue sulfhydryl groups. Arch Biochem Biophys 82(1):70-77

16. Al-Bassam J, Corbett KD (2012) Alpha-tubulin acetylation from the inside out. Proc Natl Acad Sci U S A 109(48):19515-19516

17. Oyaizu H, Adachi Y, Taketani S, Tokunaga R, Fukuhara S, Ikehara S (1999) A crucial role of caspase 3 and caspase 8 in paclitaxel-induced apoptosis. Mol Cell Biol Res Commun 2(1):36-41

18. Doudican N, Rodriguez A, Osman I, Orlow SJ (2008) Mebendazole induces apoptosis via Bcl-2 inactivation in chemoresistant melanoma cells. Mol Cancer Res 6(8):1308-1315

19. Wang LJ, Lee YC, Huang CH, Shi YJ, Chen YJ, Pi SN, Chou YW, Chang LS (2019) Non-mitotic effect of albendazole triggers apoptosis of human leukemia cells via SIRT3/ROS/p38 MAPK/TTP axismediated TNFa upregulation. Biochem Pharmacol 162:154-168

20. Pourgholami MH, Akhter J, Wang L, Lu Y, Morris DL (2005) Antitumor activity of albendazole against the human colorectal cancer cell line HT-29: in vitro and in a xenograft model of peritoneal carcinomatosis. Cancer Chemother Pharmacol 55(5):425-432

\section{Tables}

Table 1

\begin{tabular}{|lll|}
\hline Cell line & 48 hours & \\
\hline & Mebendazole (MBZ) & Albendazole (ABZ) \\
\hline $\begin{array}{l}\text { MCF-7 } \\
\text { Breast cancer cell line }\end{array}$ & $1.1 \pm 1.3 \mu \mathrm{M}$ & $8.1 \pm 1.2 \mu \mathrm{M}$ \\
\hline $\begin{array}{l}\text { MDA-MB-231 } \\
\text { Breast cancer cell line }\end{array}$ & $15.0 \pm 0.1 \mu \mathrm{M}$ & $53.3 \pm 0.2 \mu \mathrm{M}$ \\
\hline $\begin{array}{l}\text { HT29 } \\
\text { Colon cancer cell line }\end{array}$ & $0.11 \pm 0.07 \mu \mathrm{M}$ & $0.69 \pm 0.42 \mu \mathrm{M}$ \\
\hline \begin{tabular}{l} 
Mesenchymal stem cells \\
\hline
\end{tabular} & $19.9 \pm 0.1 \mu \mathrm{M}$ & $129.5 \pm 0.1 \mu \mathrm{M}$ \\
\hline
\end{tabular}


a
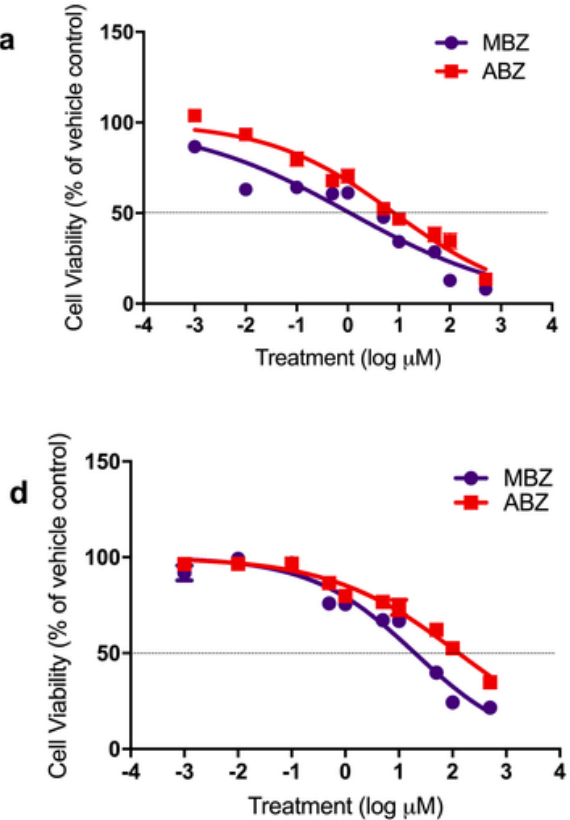
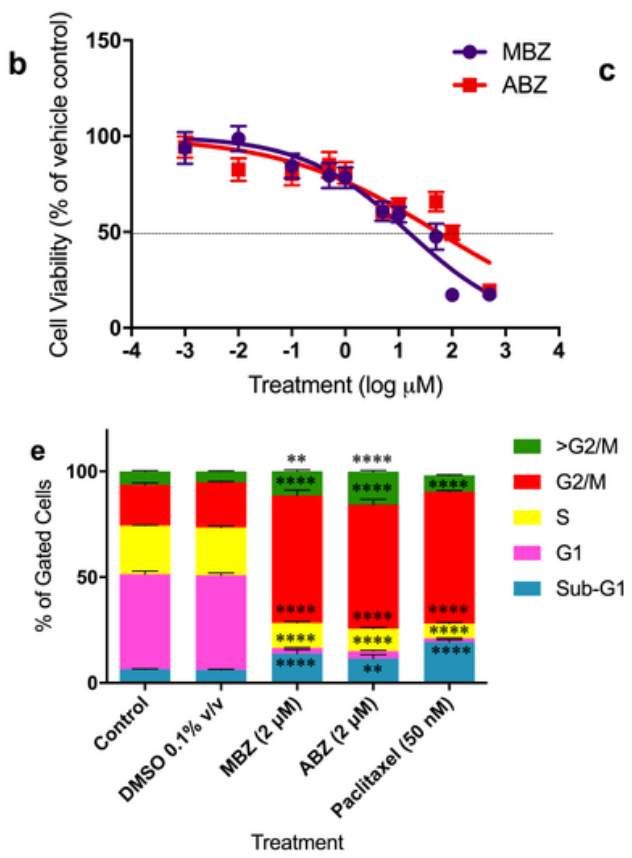
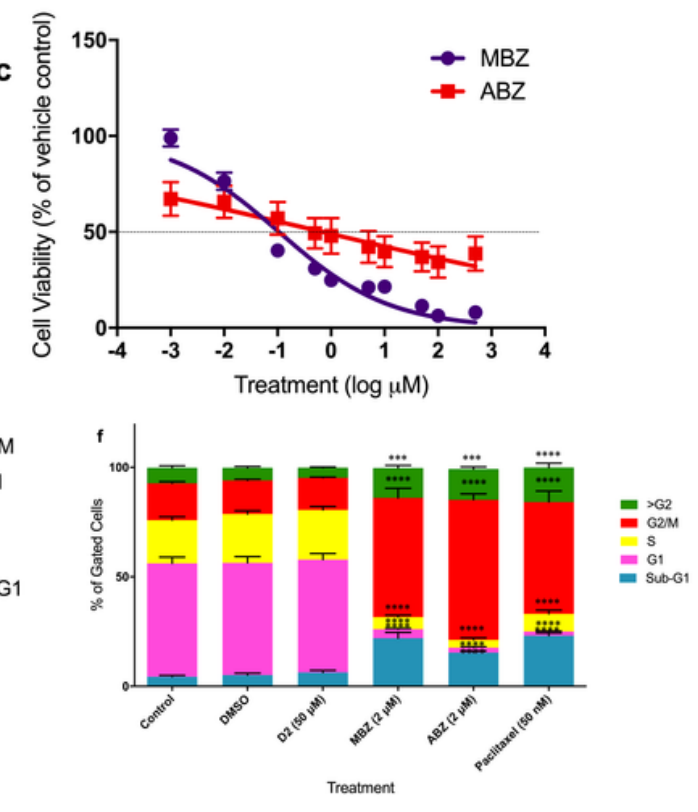

Figure 1

MBZ and ABZ reduce the cell number of cancer cell lines by inducing G2/M block and disrupting microtubule networks. Fig. 1 a-d: The MCF-7 (breast, Fig. 1a), MDA-MB-231 (breast Fig. 1b), HT-29 (colorectal, Fig. 1c) and RCB2157 (mesenchymal stem cell, Fig 1d) lines were treated with MBZ, ABZ (1 $\mathrm{nM}-500 \mu \mathrm{M})$ or DMSO vehicle control $(0.1 \% \mathrm{v} / \mathrm{v})$ for $48 \mathrm{hrs}$, and relative cell number measured with MTT assays. IC50 values and line-of-best-fit calculated using non-linear regression. Each data point represents means \pm SEM of three independent experiments $(\mathrm{N}=3)$ carried out in quadruplicate. Fig. 1e-f: Following a $24 \mathrm{hr}$ (Fig. 1e) or 48hr (Fig 1f) treatment of HT29 cells, DNA content was analysed using PI staining. Data represents mean \pm SEM of the percentage of cells at each cell cycle stage (Sub-G1; G1; S; $\mathrm{G} 2 / \mathrm{M} ;>\mathrm{G} 2 / \mathrm{M}$ ). Three independent experiments were conducted in triplicate with a minimum of 50,000 stopping events for each sample. Data was analysed using a two-way ANOVA with Dunnett's post-hoc

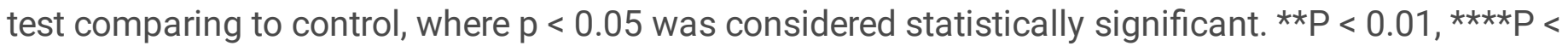
0.0001. Fig. 1g: HT-29 cells were treated with MBZ $(2 \mu \mathrm{M})$, ABZ $(2 \mu \mathrm{M})$, paclitaxel (50 nM) or DMSO vehicle control $(0.1 \% \mathrm{v} / \mathrm{v})$ for $8 \mathrm{hrs}$. Cells were stained with Hoechst 33342, anti-alpha-tubulin and antiacetylated-alpha-tubulin and imaged using the Nikon Al-R inverted fluorescent microscope with Nikon Intensilight C-HGFI mercury lamp (Olympus, Japan) at 20x magnification, with consistent exposure. 

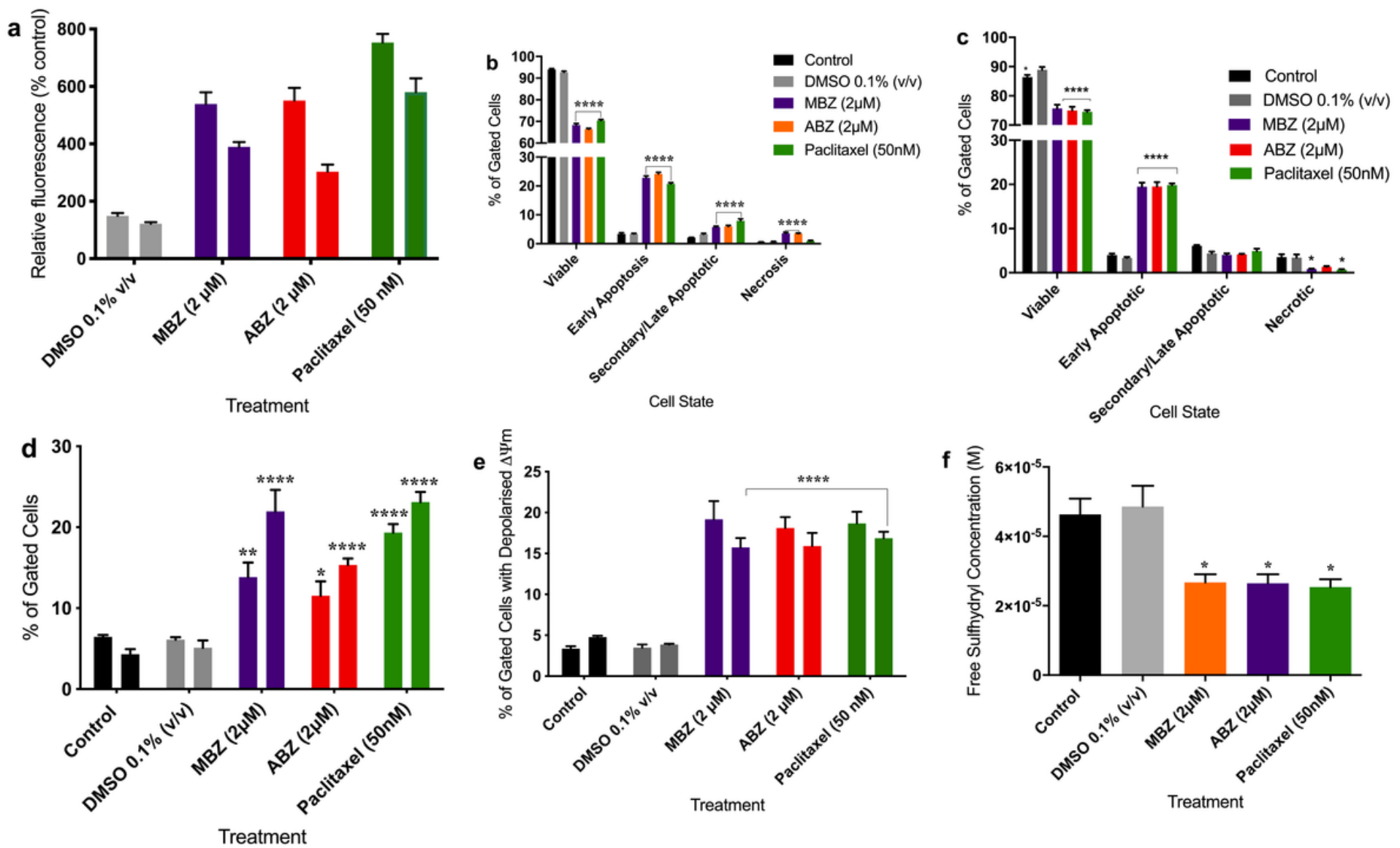

Figure 2

MBZ and ABZ induce classical apoptosis in HT29 colorectal cancer cells. HT29 cells were treated with MBZ, ABZ or DMSO vehicle control for 24 or $48 \mathrm{hrs}$, then stained for flow cytometry, fluorometry or spectroscopy. Fig. 2a: MBZ, ABZ and paclitaxel increase caspase-3 activity. Caspase-3 activity measured by fluorescent intensity using Ac-DEVD-AMC. Fig. 2b (24 hrs) and 2c (48 hrs): MBZ, ABZ and paclitaxel increase phosphatidylserine exposure. Percentage of $\mathrm{HT}-29$ cells in viable (Annexin V-/PI-), early apoptotic (Annexin V+/PI-), secondary/late necrotic (Annexin V+/PI+), or necrotic (Annexin V-/PI+) states, determined by staining with Annexin V and PI. Fig. 2d: MBZ, ABZ and paclitaxel increase sub-G1 DNA content, following $24 \mathrm{hr}$ (left bar) and $48 \mathrm{hr}$ (right bar) treatment. Fig. 2e: MBZ, ABZ and paclitaxel cause depolarisation of the mitochondrial membrane potential $(\Psi)$, determined by TMRE fluorescence intensity, following $24 \mathrm{hr}$ (left bar) and $48 \mathrm{hr}$ (right bar) treatment. Fig. 2f: MBZ, ABZ and paclitaxel decrease cellular free sulfhydryl content. The concentration of free sulfhydryls (M) in HT-29 cells was determined following $48 \mathrm{hr}$ treatment. Data represents mean \pm SEM of three independent experiments carried out in triplicate $(\mathrm{N}=3)$. Data was analysed using a one-way ANOVA with Dunnett's post-hoc test comparing to control, where $P<0.05$ was considered statistically significant. ${ }^{*} P<0.05,{ }^{\star} P P<0.01, \star \star \star \star * P<0.0001$ 